\title{
PENGARUH PENYISIPAN LOGAM Fe DENGAN BERBAGAI VARIASI MASSA PADA LAPISAN AKTIF TITANIA TERHADAP STRUKTUR MORFOLOGI, SPEKTRUM ABSORBANSI, RESISTANSI DAN PERFORMANSI SEL SURYA
}

\section{THE INSERTION EFFECT OF Fe METAL WITH MASS VARIATION ON TITANIA ACTIVE LAYER TO THE MORPHOLOGICAL STRUCTURE, ABSORBANCE SPECTRA, RESISTANCE, AND SOLAR CELLS PERFORMANCE}

\author{
Rita Prasetyowati*, Laila Katriani, and Windya Setya Ningtias \\ Jurusan Pendidikan Fisika, FMIPA, Universitas Negeri Yogyakarta \\ *email: Rita_P@uny.ac.id
}

Diterima 12 Agustus 2016 disetujui 5 September 2016

\begin{abstract}
Abstrak
Penelitian ini bertujuan untuk mengetahui pengaruh penyisipan logam Fe dengan berbagai variasi massa terhadap struktur morfologi lapisan titania, spektrum absorbansi lapisan titania, resistansi lapisan titania, dan performansi (tegangan) sel surya. Preparasi lapisan titania-besi $\left(\mathrm{TiO}_{2}\right)$ menjadi bentuk pasta dilakukan dengan menggunakan metode sol-gel. Pasta titania-besi dideposisikan pada elektroda transparan (Indium Tin Oxide) dengan metode doctor blade. Dilakukan lima variasi massa Fe yang disisipkan pada $1 \mathrm{~g}$ lapisan titania aktif, yaitu 0,$050 ; 0,075 ; 0,100 ; 0,125$; dan $0,150 \mathrm{~g}$. Hasil analisis SEM menunjukkan bahwa penyisipan logam $\mathrm{Fe}$ tidak mempengaruhi struktur morfologi lapisan titania, meskipun hasil EDS menunjukkan adanya logam $\mathrm{Fe}$ pada lapisan titania tersebut. Lapisan $\mathrm{TiO}_{2}$ dan lapisan $\mathrm{TiO}_{2}-\mathrm{Fe}$ dapat menyerap cahaya dengan baik pada panjang gelombang 200-390 nm dan pada panjang gelombang 650-800 nm. Lapisan $\mathrm{TiO}_{2}-\mathrm{Fe}$ memiliki nilai absorbansi yang lebih besar daripada lapisan $\mathrm{TiO}_{2}$. Nilai resistansi untuk lapisan $\mathrm{TiO}_{2}$ yaitu $3.190 \Omega$. Sedangkan nilai resistansi untuk lapisan titania sampel 1, 2, 3, 4 dan 5 secara berturut-turut adalah 3188,49; 3188,$40 ; 3188,39 ; 3187,98$ dan $3184.87 \Omega$. Besarnya tegangan sel surya yang menggunakan lapisan titania sampel 1, 2, 3, 4 dan 5 secara berturut-turut adalah 0,$370 ; 0,398 ; 0,334 ; 0,488$; dan 0,545 Volt. Kata kunci: titania, besi, struktur morfologi, absorbansi, resistansi, tegangan, sel surya
\end{abstract}

\begin{abstract}
This study aims to determine the effect of Fe metal insertion with a variety of mass to the morphological structure, absorbance spectrum, the resistance, and solar cells performance. Preparation of $\mathrm{TiO}_{2}-\mathrm{Fe}$ to form a paste made using sol-gel method. Pasta $\mathrm{TiO}_{2}$-Fe deposited on a transparent electrode (Indium Tin Oxide) with a doctor blade method. There were five variations of mass $F e$ is pasted on a layer of $1 \mathrm{~g}$ titania, namely $0.050 ; 0.075 ; 0.100 ; 0.125$; and $0.150 \mathrm{~g}$. SEM analysis showed that the insertion Fe on titania layer does not affect the structure morphology of the titania, even the EDS results showed that the composition of $\mathrm{TiO}_{2}-\mathrm{Fe}$ contains Ti element. A layer of $\mathrm{TiO}_{2}$ and $\mathrm{Fe}-\mathrm{TiO}_{2}$ coating can absorb light very well at a wavelength of 200$390 \mathrm{~nm}$ and at a wavelength of 650-800 $\mathrm{nm}$. TiO $\mathrm{O}_{2}-\mathrm{Fe}$ layers have absorbance values greater than the $\mathrm{TiO}_{2}$ layer. The resistance value for $\mathrm{TiO}_{2}$ layer is 3,190 $\Omega$. While the resistance value for titania coating samples 1 , 2, 3, 4 and 5 respectively are 3,188.49; 3,188.40; 3,188.39; 3,187.98 and 3,184.87Q. The magnitude of the voltage solar cells that use titania coating samples 1, 2, 3, 4 and 5 are $0.370,0.398,0.334,0.488$ and 0.545 volt, respectively.
\end{abstract}

Keywords: titania, iron, structure morphology, absorbance, resistance, voltage, solar cells

\section{Pendahuluan}

Kebutuhan masyarakat akan penggunaan energi listrik semakin hari semakin meningkat. Sedangkan persediaan energi di seluruh dunia, termasuk di dalamnya energi listrik, semakin hari semakin menipis Ketersediaan sumber energi listrik konvensional semakin tidak mampu untuk mengimbangi kebutuhan masyarakat akan energi listrik. Berbagai upaya terus dilakukan untuk mencari dan mengembangkan sumber energi listrik yang baru. Sel surya merupakan salah satu sumber 
energi listrik alternatif masa depan yang diharapkan mampu mengatasi kekurangan energi listrik.

Perkembangan sel surya terus menerus dilakukan, dari sel surya generasi pertama, kedua dan ketiga. Sel surya generasi pertama (wafer silikon dan pita silikon) dan sel surya generasi kedua (lapisan tipis) memiliki efisiensi yang baik, yaitu mencapai $20 \%$. Tetapi sel surya tersebut dalam produksinya memerlukan teknologi tinggi dan biayanya sangat mahal. Sel surya generasi ketiga yaitu sel surya organik dan sel surya fotoelektrokimia dalam proses produksinya relatif mudah dan harganya murah. Tetapi sel surya generasi ketiga masih memiliki efisiensi rendah dan umur pakai yang singkat [1].

Penelitian tentang sel surya generasi ketiga terus dikembangkan untuk menghasilkan sel surya dengan efisiensi yang lebih baik. Salah satu sel surya generasi ketiga adalah sel surya yang dibuat dengan bahan semikonduktor titanium dioksida. Berbagai penelitian terhadap sel surya titania terus menerus dilakukan untuk menghasilkan sel surya titania dengan efisiensi yang lebih baik, diantara menghasilkan sel surya jenis DSSC (dye sensitized solar cell) dan sel surya titania dengan penyisipan logam. Pada penelitian ini dipelajari pengaruh penyisipan logam besi dengan berbagai variasi massa pada lapisan aktif titania terhadap struktur morfologi, komposisi bahan dan resistansi lapisan titania, serta performansi sel surya yang dihasilkan.

\section{Metode Penelitian}

Teknik pengambilan data dilakukan dalam dua tahap yaitu tahap preparasi (pembuatan lapisan titania) dan tahap karakterisasi lapisan titania.

a. Tahap Preparasi (pembuatan lapisan titania)

1. Pembuatan nanokomposit titania-besi. PVA sebanyak 0,1 gram dilarutkan dalam $10 \mathrm{ml}$ aquades, kemudian larutan tersebut diaduk sambil dipanaskan di atas hot plate pada suhu $80^{\circ} \mathrm{C}$ selama 2 jam, larutan ini berfungsi sebagai binder dalam pembuatan pasta nanokomposit. Selanjutnya $\mathrm{TiO}_{2}$ sebanyak 1 gram dan Fe sebanyak 0,05 gram dimasukkan ke dalam binder, sambil tetap diaduk dan dipanaskan pada suhu $80^{\circ} \mathrm{C}$ sampai terbentuk pasta nanokomposit yang baik $( \pm 1$ jam). Dilakukan juga langkah yang sama untuk penambahan $\mathrm{Fe}$ sebanyak 0,075 gram, 0,100 gram, 0,125 gram dan 0,150 gram.
2. Deposisi nanokomposit titania-besi pada substrat elektroda transparan. Elektroda transparan dipotong dengan ukuran $2 \mathrm{~cm} \mathrm{x}$ $2,5 \mathrm{~cm}$, kemudian dicuci dengan aquades selama 15 menit dan dengan alkohol $70 \%$ selama 30 menit menggunakan ultrasonic bath . Nanokomposit yang telah dibuat selanjutnya dicetakkan di atas elektroda transparan yang sudah bersih dengan teknik doctor blade. Nanokomposit yang telah menempel pada elektroda transparan kemudian dipanaskan di atas hot plate pada suhu $100^{\circ} \mathrm{C}$ selama 30 menit, selanjutnya dipanaskan dengan menggunakan furnace pada suhu $450^{\circ} \mathrm{C}$ selama 30 menit.

3. Pembuatan lapisan elektrolit. $\mathrm{NaF}$ sebanyak 0,5 gram dilarutkan dalam $10 \mathrm{ml}$ aquades sambil diaduk menggunakan stirrer sampai terlarut semua, kemudian 0,8 gram PVA dimasukkan sedikit demi sedikit sambil terus diaduk dan dipanaskan pada suhu $110^{\circ} \mathrm{C}$ sampai pelarut aquades menguap atau terbentuk gel. Gel elektrolit dilapiskan secara manual pada lapisan pasta $\mathrm{TiO}_{2}+\mathrm{Fe}$. Langkah terakhir adalah pemberian elektroda aluminium.

\section{b. Tahap Karakterisasil Lapisan Titania}

Struktur morfologi permukaan lapisan titania dianalisis dengan SEM, sedangkan komposisi bahan dianalisis dengan EDS. Spektrum absorbansi lapisan dianalisis dengan menggunakan spektrometer Uv-Visible. Resistansi lapisan titania dianalisis dengan menggunakan Jembatan Wheatstone. Tegangan sel surya diukur dengan menggunakan multimeter.

\section{Hasil dan Pembahasan}

a. Struktur Morfologi dan Komposisi Kimia Lapisan $\mathrm{TiO}_{2}$ dan $\mathrm{TiO}_{2}-\mathrm{Fe}$

Struktur morfologi lapisan $\mathrm{TiO}_{2}$ dan lapisan $\mathrm{TiO}_{2}-\mathrm{Fe}$ diperoleh dari hasil karakterisasi menggunakan SEM (Scanning Electron Microscopy). Berdasarkan hasil analisis SEM dapat diperoleh morfologi permukaan dan ukuran butir dari suatu bahan. Teknik SEM menghasilkan foto morfologi permukaan bahan dengan berbagai tonjolan dan lekukan yang didapatkan dari pengolahan elektron sekunder yang dipancarkan oleh bahan. 
Hasil SEM lapisan $\mathrm{TiO}_{2}$ sebagai pembanding merujuk pada penelitian sebelumnya, yang dilakukan oleh Rita Prasetyowati pada tahun 2011. Morfologi permukaan lapisan $\mathrm{TiO}_{2}$ ditunjukkan pada Gambar 1. Partikel-partikel $\mathrm{TiO}_{2}$ yang terdeposisi pada ITO mempunyai butiran (grain) yang cukup homogen. Dari gambar tersebut dapat dihitung bahwa ukuran diamater partikel $\mathrm{TiO}_{2}$ sekitar $180 \mathrm{~nm}$ (berdasarkan distribusi ukuran partikel pada Gambar 2). Ryan O'Hyre, dkk (2006) menyatakan bahwa ukuran partikel $\mathrm{TiO}_{2}$ sebesar 50-200 nm mendukung performansi sel surya untuk menjadi lebih baik. Pada Gambar 3 ditunjukkan hasil EDS lapisan $\mathrm{TiO}_{2}$. Hasil EDS tersebut memperlihatkan bahwa komposisi bahan yang terkandung dalam lapisan $\mathrm{TiO}_{2}$ adalah unsur Ti sebanyak $54,25 \%$ dan unsur $\mathrm{O}$ sebanyak $45,75 \%$.

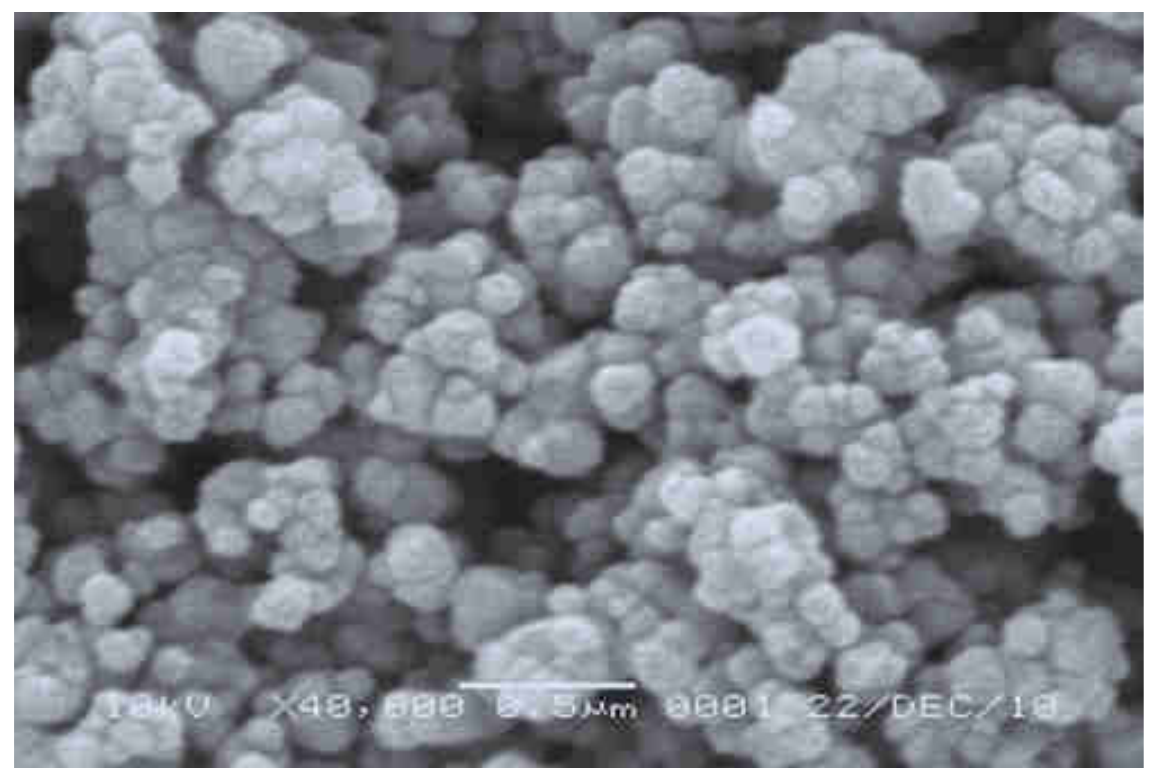

Gambar 1. Foto SEM pasta $\mathrm{TiO}_{2}$ yang dideposisikan pada ITO dengan teknik printing.

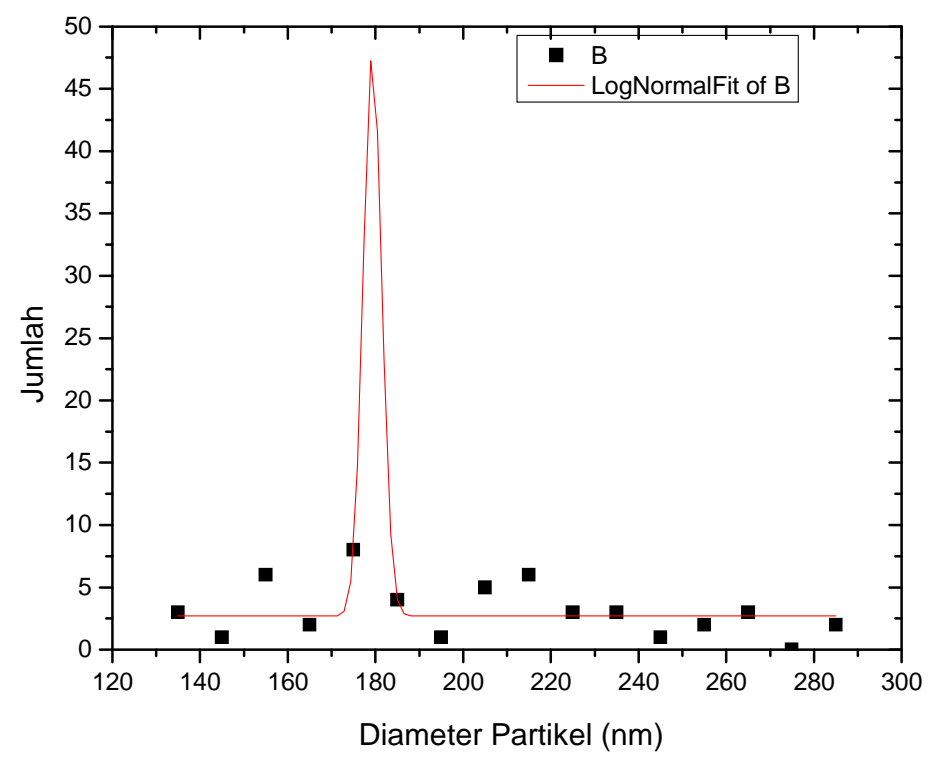

Gambar 2. Distribusi ukuran partikel $\mathrm{TiO}_{2}$ dari hasil citra SEM 


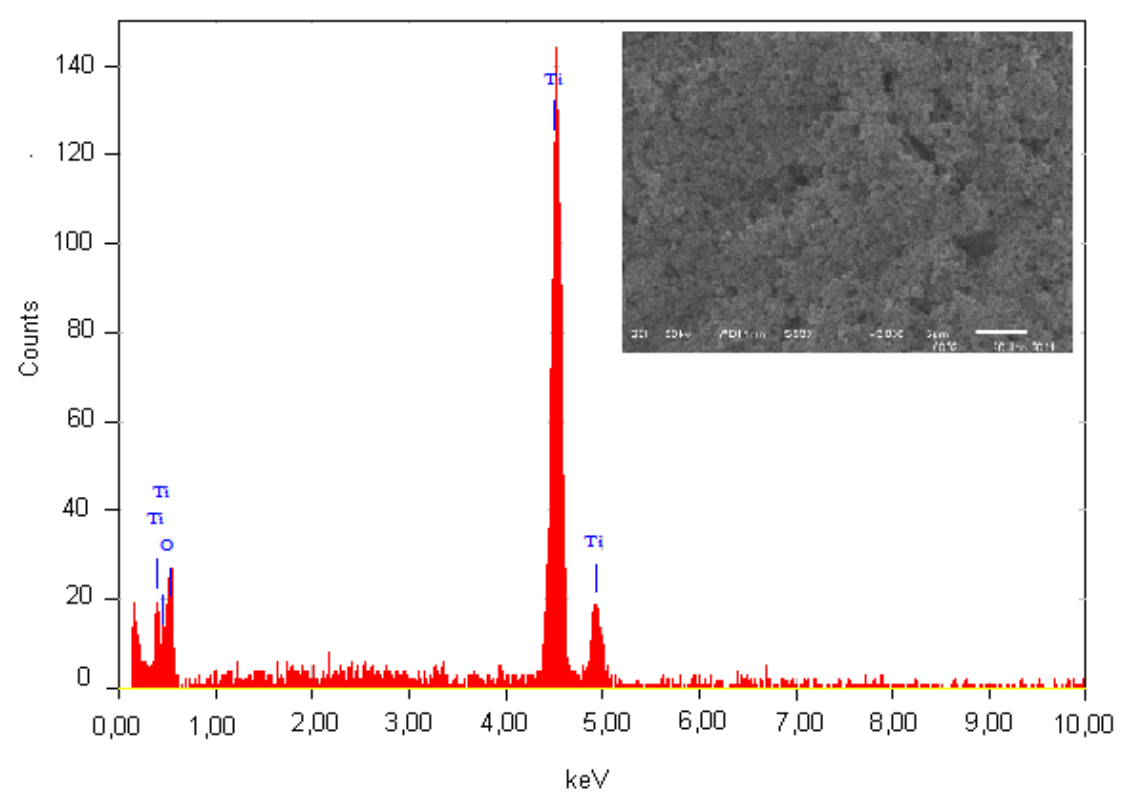

Gambar 3. Hasil EDS lapisan $\mathrm{TiO}_{2}$.

Morfologi permukaan lapisan $\mathrm{TiO}_{2}-\mathrm{Fe}$ (sampel 5) ditunjukkan pada Gambar 4. Berdasarkan gambar tersebut terlihat bahwa butiran (grain) partikel-partikel $\mathrm{TiO}_{2}$-Fe cukup homogen, dengan ukuran rata-rata diameter partikel sebesar $145 \mathrm{~nm}$ (Gambar 5). Morfologi permukaan pada lapisan $\mathrm{TiO}_{2}-\mathrm{Fe}$ tidak menunjukkan perbedaan yang signifikan dengan morfologi permukaan lapisan $\mathrm{TiO}_{2}$ tanpa penambahan Fe. Tetapi berdasarkan hasil EDS pada Gambar 6, tebukti bahwa pada lapisan $\mathrm{TiO}_{2}-\mathrm{Fe}$ mengandung sejumlah $\mathrm{Fe}$. Hal ini berarti ada partikel-partikel $\mathrm{Fe}$ yang menyisip diantara partikel-partikel $\mathrm{TiO}_{2}$ ketika dilakukan pembuatan pasta nanokomposit $\mathrm{TiO}_{2}-\mathrm{Fe}$. Berdasarkan hasil EDS pada Gambar 5 dapat diketahui bahwa lapisan $\mathrm{TiO}_{2}-\mathrm{Fe}$ mengandung unsur Ti sebanyak 59,82 \%, unsur $\mathrm{O}$ sebanyak $40,03 \%$ dan unsur Fe sebanyak 0,15\%.

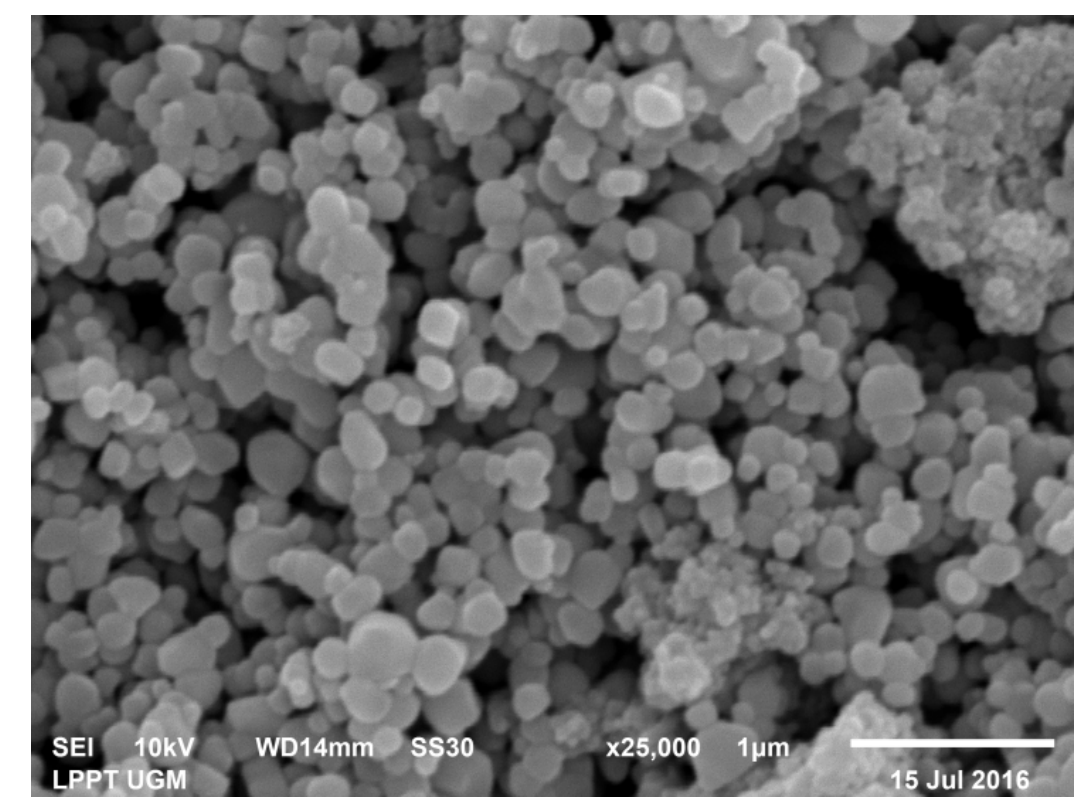

Gambar 4. . Foto SEM pasta $\mathrm{TiO}_{2}-\mathrm{Fe}$ (sampel 5) yang dideposisikan pada ITO dengan teknik doctor blade 


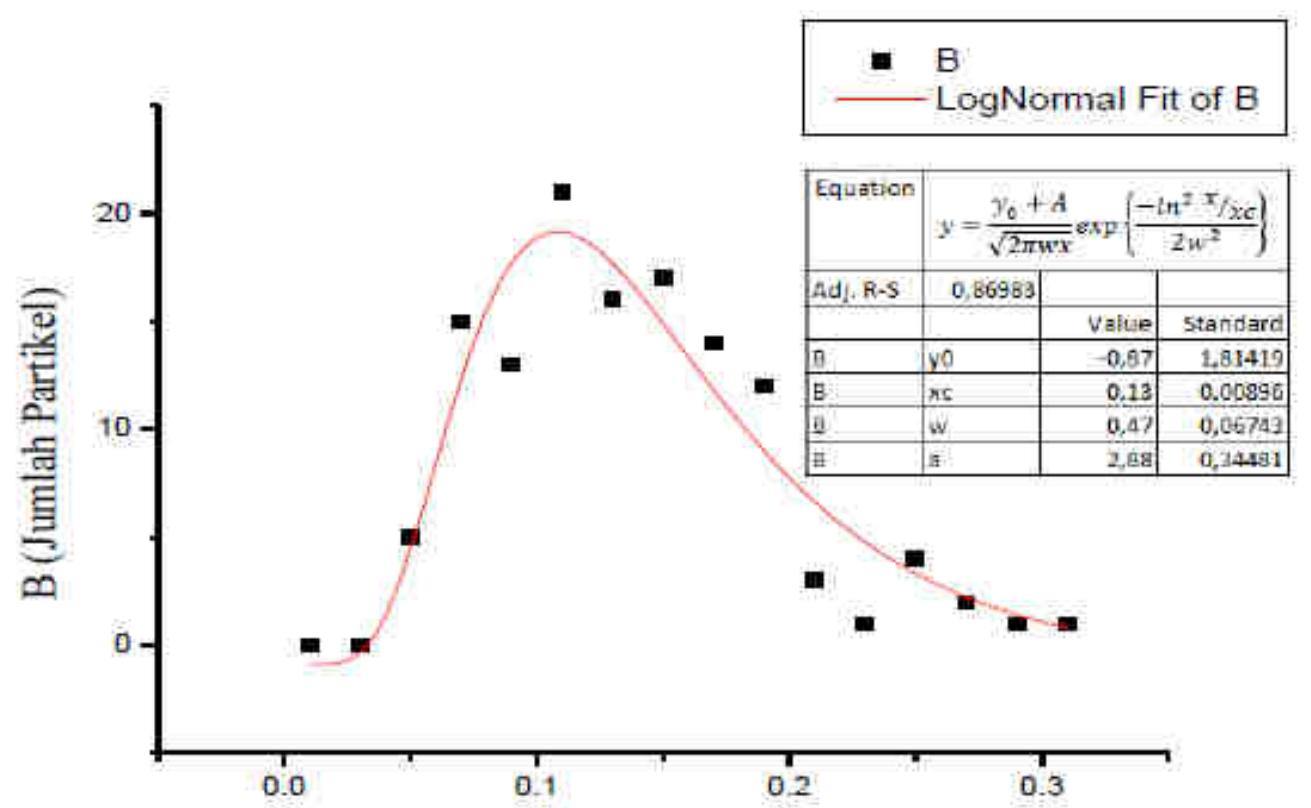

A (Ukuran Partikel dalam Mikron)

Gambar 5. Distribusi ukuran partikel $\mathrm{TiO}_{2}-\mathrm{Fe}$ (sampel 5) dari hasil citra SEM

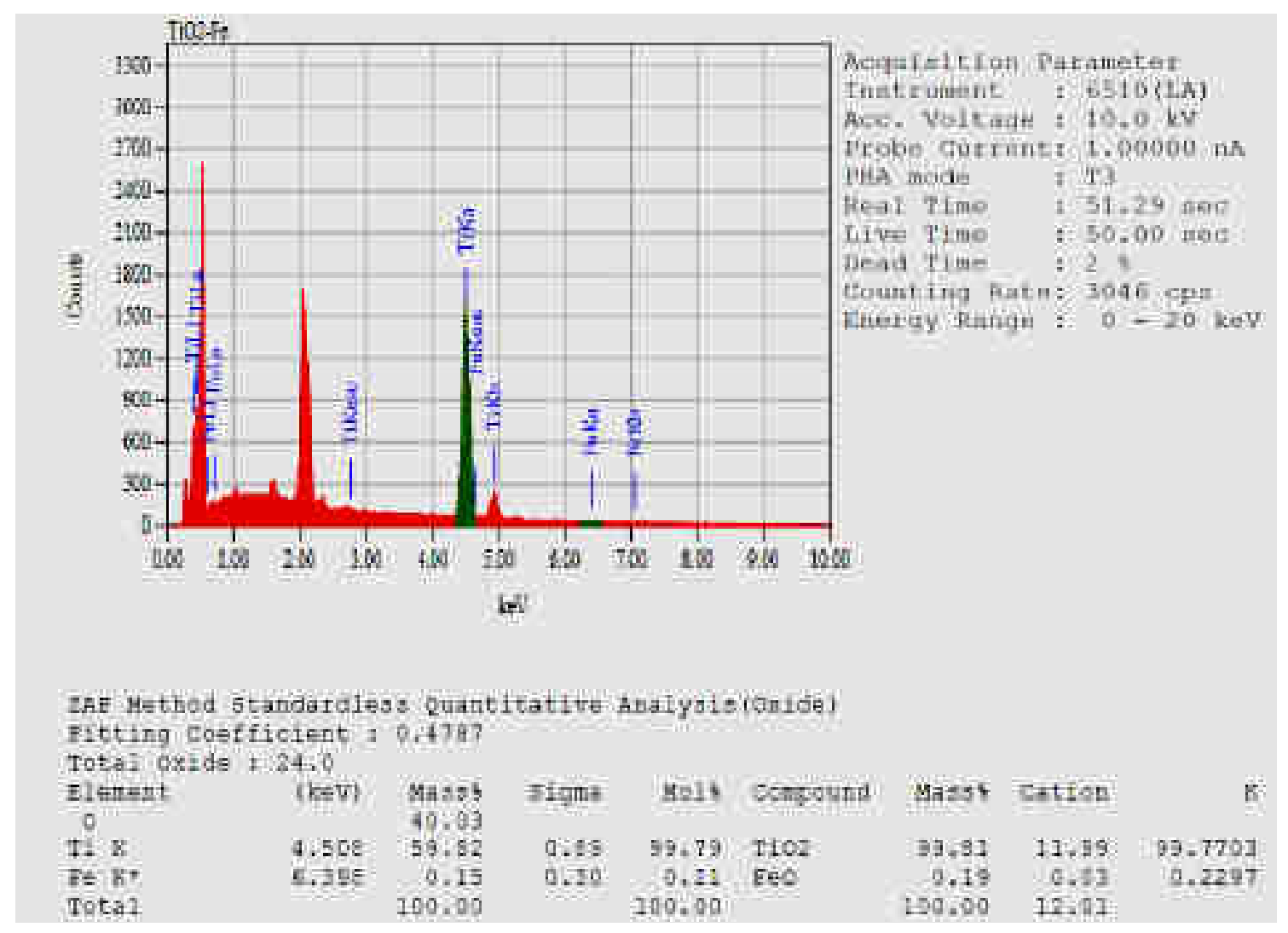

Gambar 6. Hasil EDS lapisan $\mathrm{TiO}_{2}-\mathrm{Fe}$ (sampel 5)

b. Absorbansi Lapisan $\mathrm{TiO}_{2}$ dan $\mathrm{TiO}_{2}-\mathrm{Fe}$

Pada penelitian ini dilakukan uji absorbansi pada sampel $\mathrm{TiO} 2$ dan $\mathrm{TiO} 2-\mathrm{Fe}$ dengan rentang panjang gelombang yang digunakan antara 200-800 nm, dengan menggunakan UV 1700 Pharmaspec UV-Vis Spectrophotometer. 


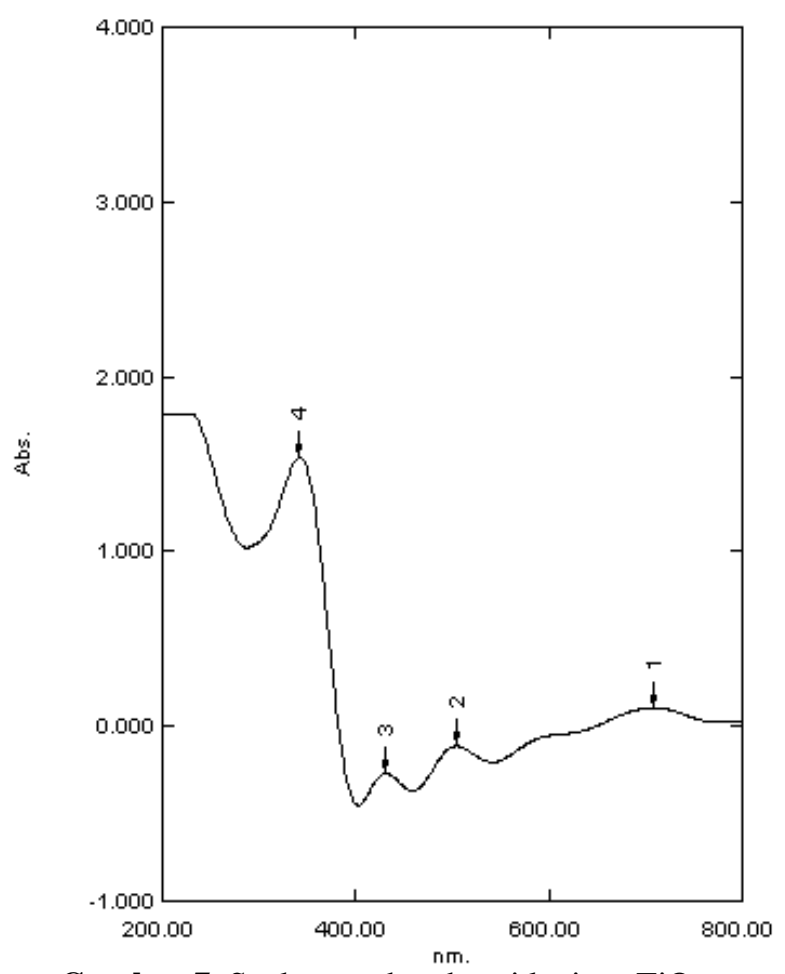

Gambar 7. Spektrum absorbansi lapisan $\mathrm{TiO}_{2}$

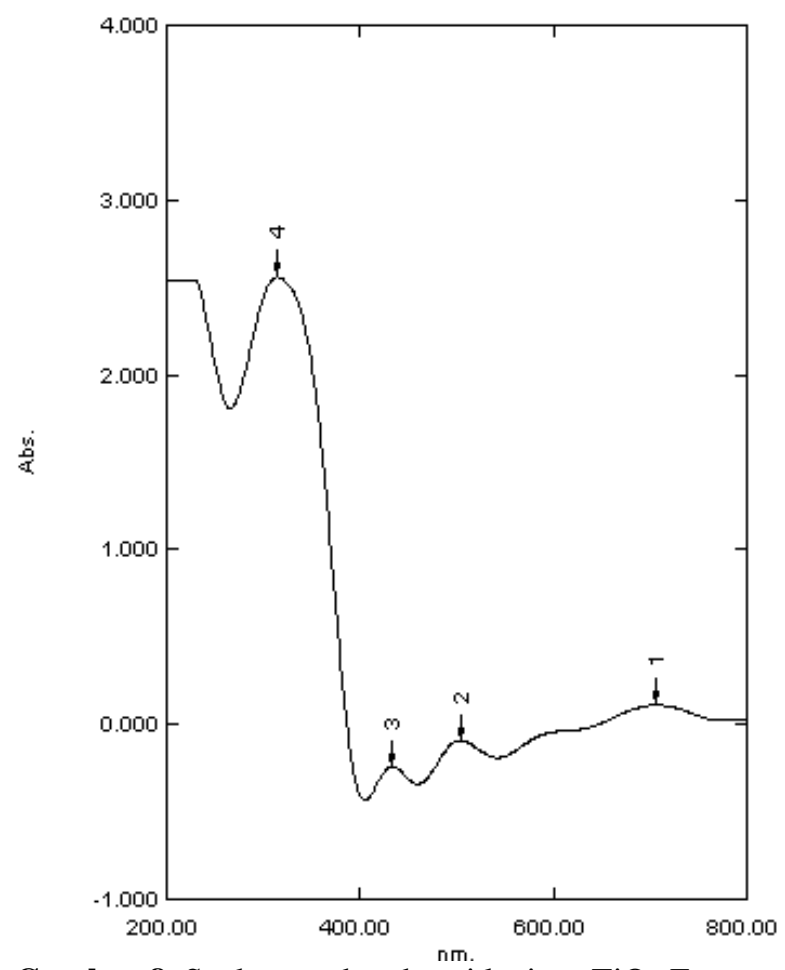

Gambar 8. Spektrum absorbansi lapisan $\mathrm{TiO}_{2}-\mathrm{Fe}$

Berdasarkan Gambar 7 dan Gambar 8 dapat dilihat bahwa lapisan $\mathrm{TiO}_{2}$ dan $\mathrm{TiO}_{2}-\mathrm{Fe}$ dapat menyerap cahaya dengan baik pada panjang gelombang 200-390 nm dan 650-800 nm. Pada lapisan $\mathrm{TiO}_{2}$ puncak serapan terjadi pada panjang gelombang $341 \mathrm{~nm}$ (dengan absorbani 1,538) dan
$708 \mathrm{~nm}$ (dengan absorbansi 0,104). Sedangkan pada lapisan $\mathrm{TiO}_{2}-\mathrm{Fe}$ puncak serapan terjadi pada panjang gelombang $315 \mathrm{~nm}$ (dengan asborbansi 2,559) dan $706 \mathrm{~nm}$ (dengan absorbansi 0,110). Meskipun lapisan $\mathrm{TiO}_{2}$ dan lapisan $\mathrm{TiO}_{2}-\mathrm{Fe}$ dapat menyerap cahaya pada rentang gelombang yang sama dan memiliki puncak serapan yang hampir sama, tetapi absorbansi lapisan $\mathrm{TiO}_{2}-\mathrm{Fe}$ lebih besar.

c. Resistivitas Listrik Lapisan $\mathrm{TiO}_{2}-\mathrm{Fe}$

Konduktivitas listrik lapisan $\mathrm{TiO}_{2}$ dan $\mathrm{TiO}_{2}-\mathrm{Fe}$ ditentukan dengan menggunakan rangkaian Jembatan Wheatstone. Rangkaian Jembatan Wheatstone dapat digunakan untuk mengukur resistansi dari suatu hambatan. Rangkaian Jembatan Wheatstone yang digunakan dalam penelitian ini ditunjukkan oleh Gambar 9.

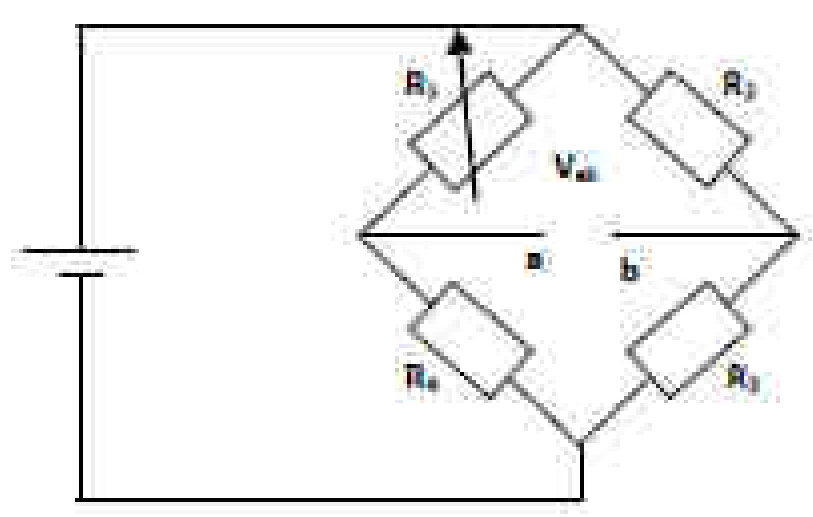

Gambar 9. Rangkain Jembatan Wheatstone

Pada rangkaian Jembatan Wheatstone tersebut, $\mathrm{R}_{1}$ adalah potensiometer $3 \mathrm{k} \Omega, \mathrm{R}_{2}=\mathrm{R}_{3}$ yaitu resistor $18 \Omega, \quad V_{a b}$ adalah tegangan yang dicari dan $R_{4}$ adalah resistor yang belum diketahui nilai resistansinya. Sampel lapisan $\mathrm{TiO}_{2}$ ataupun $\mathrm{TiO}_{2}{ }^{-}$ $\mathrm{Fe}$ menempati posisi sebagai $\mathrm{R}_{4}$.

Hasil pengukuran nilai resistansi lapisan $\mathrm{TiO}_{2}$ adalah sebesar $3190 \Omega$. Hasil perhitungan nilai resistansi dari kelima sampel $\mathrm{TiO}_{2}-\mathrm{Fe}$ memberikan hasil seperti pada Tabel 1.

Tabel 1. Hasil Pengukuran Nilai Resistansi

\begin{tabular}{cc}
\hline Sampel & Resistansi (Ohm) \\
\hline 1 (Fe 0,050 gram) & 3188,49 \\
2 (Fe 0,075 gram) & 3188,40 \\
3 (Fe 0,100 gram) & 3188,39 \\
4 (Fe 0,125 gram) & 3187,98 \\
5 (Fe 0,150 gram) & 3184.87 \\
\hline
\end{tabular}

Berdasarkan hasil pengukuran tersebut, dapat dilihat bahwa nilai resistansi lapisan $\mathrm{TiO}_{2}-\mathrm{Fe}$ 
sampel 1 lebih kecil daripada nilai resistansi lapisan $\mathrm{TiO}_{2}-\mathrm{Fe}$ sampel 2 dan sampel 3. Hal ini berarti penyisipan partikel logam $\mathrm{Fe}$ pada lapisan $\mathrm{TiO}_{2}$ dapat memperkecil nilai resistansi lapisan tersebut. Logam $\mathrm{Fe}$ yang menyisip diantara partikel $\mathrm{TiO}_{2}$ berperan sebagai kontak logam yang menjadi lintasan bagi elektron untuk mengalir lebih cepat menuju ITO (R. Sastrawan, 2006).

\section{d. Performansi Sel Surya Berbasis $\mathrm{TiO}_{2}$ dengan Penyisipan Logam Fe}

Sampel sel surya yang telah berbentuk sandwich (seperti Gambar 10) dikarakterisasi untuk mengetahui performansinya. Performansi yang dimaksudkan disini hanya tegangannya saja karena pengukuran arus-tegangan dengan menggunakan IV-meter tidak dapat dilakukan. Tegangan diukur dengan menggunakan multimeter. Hasil pengukuran tegangan dari kelima sampel seperti tercantum pada Tabel 2.

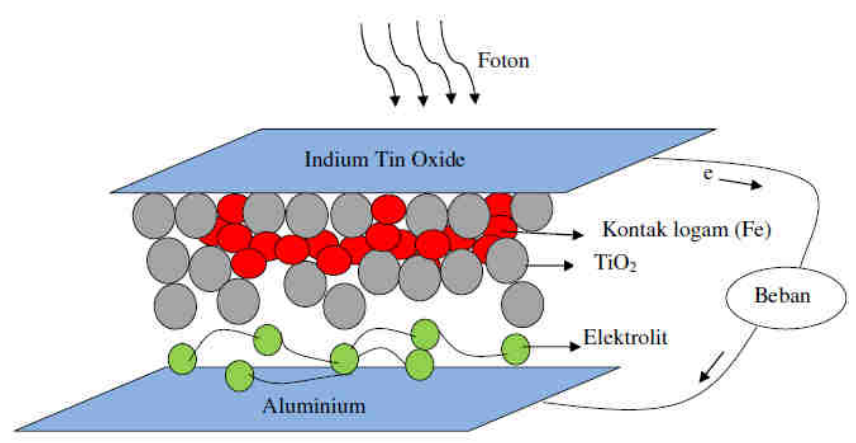

Gambar 10. Struktur sel surya berbasis $\mathrm{TiO}_{2}$ dan logam $\mathrm{Fe}$

Tabel 2. Hasil Pengukuran Tegangan Sel Surya

\begin{tabular}{ccc}
\hline No & Sampel & Tegangan (Volt) \\
\hline 1 & 1 (Fe 0,050 gram) & 0,370 \\
2 & 2 (Fe 0,075 gram) & 0,398 \\
3 & 3 (Fe 0,100 gram) & 0,334 \\
4 & 4 (Fe 0,125 gram) & 0,488 \\
5 & 5 (Fe 0,150 gram) & 0,545 \\
\hline
\end{tabular}

Berdasarkan Tabel 2 terlihat bahwa nilai tegangan yang dihasilkan bermacam-macam sesuai dengan variasi massa besi yang disisipkan. Peneliti sudah mencoba mengukur arus-tegangan dengan menggunaan El-Kahfi 100, dengan sumber cahaya yang berasal dari lampu halogen yang memiliki intensitas cahaya sebesar $18 \mathrm{~W} / \mathrm{m} 2$ atau setara dengan 500 Lux. Tetapi grafik yang dihasilkan masih tetap belum sesuai dengan yang diharapkan, sehingga kurva I-V belum bisa digambarkan. Tetapi Sel surya yang dibuat dalam bentuk prototype ini sudah bisa menunjukkan adanya gejala fotovoltaik, karena sudah ada tegangan yang dihasilkan.

Adanya atom-atom $\mathrm{Fe}$ yang menyisip diantara partikel-partikel $\mathrm{TiO}_{2}$ dalam jumlah yang cukup dapat memberikan efek bahwa sel surya yang dihasilkan memberikan tegangan yang lebih besar. Hal ini bisa dijelaskan seperti pada Gambar 10, ketika sel surya diradiasi dengan cahaya maka akan terjadi generasi (timbulnya pasangan elektronhole). Foton yang diserap oleh elektron pada $\mathrm{TiO}_{2}$ menyebabkan elektron tereksitasi dari keadaan dasar ke keadaan tereksitasi dan selanjutnya elektron mengalir menuju ITO melalui lapisan kontak logam $(\mathrm{Fe})$. Kemudian elektron mengalir melalui beban luar menuju counter elektroda dan akan diterima oleh elektrolit. Sedangkan hole yang terbentuk akan berdifusi menuju elektrolit. Hal ini berarti elektron yang diterima elektrolit akan berekombinasi dengan hole membentuk pembawa muatan negatif (K. Asagoe, dkk, 2007).

Ketika lapisan $\mathrm{TiO}_{2}$ disisipi dengan $\mathrm{Fe}$, berarti ada atom-atom $\mathrm{Fe}$ yang menyisip di antara $\mathrm{TiO}_{2}$. Akibatnya lapisan $\mathrm{TiO}_{2}$ memiliki lapisan kontak logam. Lapisan kontak logam ini menjadi lintasan bagi elektron untuk mengalir lebih cepat menuju ITO. Terjadinya lintasan bagi elektron pada lapisan $\mathrm{TiO}_{2}$ dapat dianalogikan sebagai proses persambungan antara logam-semikonduktor, dimana ketika terjadi kontak antara logam dengan semikonduktor maka elektron pada semikonduktor akan mengalir pada logam (R. Sastrawan, 2006). Sehingga elektron hasil generasi pada $\mathrm{TiO}_{2}$ akan menuju ke logam, dan bersama-sama dengan elektron pada logam akan mengalir menuju ITO. Hal ini dapat meningkatkan performansi sel surya.

\section{Simpulan}

Penyisipan logam Fe pada lapisan titania tidak mempengaruhi struktur morfologi lapisan titania jika dilihat dari hasil karakterisasi SEM. Butiran (grain) yang terbentuk pada kedua lapisan tersebut relatif sama. Hasil EDS memperlihatkan bahwa komposisi bahan pada kedua lapisan tersebut berbeda. Lapisan $\mathrm{TiO}_{2}-\mathrm{Fe}$, yaitu lapisan $\mathrm{TiO}_{2}$ yang disisipi logam tembaga mengandung unsur $\mathrm{Ti}$ sebanyak $59,82 \%$, unsur O sebanyak 40,03\% dan unsur Fe sebanyak 0,15\%. Sedangkan lapisan $\mathrm{TiO}_{2}$ saja mengandung unsur Ti sebanyak $54,25 \%$ dan unsur O sebanyak $45,75 \%$.

Lapisan $\mathrm{TiO}_{2}$ dan $\mathrm{TiO}_{2}$-Fe dapat menyerap cahaya dengan baik pada panjang gelombang 200$390 \mathrm{~nm}$ dan 650-800 nm. Pada lapisan $\mathrm{TiO}_{2}$ puncak 
serapan terjadi pada panjang gelombang $341 \mathrm{~nm}$ (dengan absorbani 1,538) dan $708 \mathrm{~nm}$ (dengan absorbansi 0,104). Sedangkan pada lapisan $\mathrm{TiO}_{2}-\mathrm{Fe}$ puncak serapan terjadi pada panjang gelombang $315 \mathrm{~nm}$ (dengan asborbansi 2,559) dan $706 \mathrm{~nm}$ (dengan absorbansi 0,110).

Nilai resistansi untuk lapisan $\mathrm{TiO}_{2}$ yaitu 3.190 $\Omega$. Sedangkan nilai resistansi untuk lapisan titania sampel 1, 2, 3, 4 dan 5 secara berturut-turut adalah $3188,49 \Omega ; 3188,40 \Omega ; 3188,39 \Omega ; 3187,98 \Omega$ dan $3184.87 \Omega$. Sedangkan besarnya tegangan sel surya yang menggunakan lapisan titania sampel 1, 2, 3, 4 dan 5 secara berturut-turut adalah 0,370; 0,398; 0,334; 0,488; dan 0,545 V.

\section{Ucapan Terima Kasih}

Peneliti mengucapkan terimakasih kepada FMIPA UNY yang telah membiayai penelitian ini melalui anggaran DIPA BLU Universitas Negeri Yogyakarta Tahun 2015.

\section{Pustaka}

[1] B. Yuliarto (2006). Berita Iptek 20 Januari 2006

[2] B.R. O'Hayre, M. Nanu, J. Schoonman, A. Goossens, Q. Wang dan M. Grätzel. (2006). The Influence of $\mathrm{TiO}_{2}$ Particle Size in $\mathrm{TiO}_{2} / \mathrm{CuInS}_{2}$ Nanocomposite Solar Cells, $A d v$. Funct. Mater. 16, 1566-1576

[3] R. Prasetyowati. (2011). Studi Pengembangan Sel Surya Berbasis $\mathrm{TiO}_{2}$ Melalui Penyisipan Logam Fe dengan Metode Elektroplating. Tesis. Institut Teknologi Bandung

[4] R. Sastrawan. (2006). Photovoltaic modules of dye solar cells. Ph.D Thesis, Universität Freiburg 